\title{
Olympic Games Rio 2016 and the uninvited viruses: Potential consequences for Europe and North America
}

\author{
Juegos Olímpicos de Río 2016 y los virus no invitados: posibles \\ consecuencias para Europa y América del Norte
}

In the Latin American tropics, we have witnessed the emergence of several pathogenic arboviruses in the last decade. These include Yellow Fever, West Nile virus, St. Louis encephalitis, Venezuelan equine encephalitis, Mayaro, Oropouche, Ilheus, and most recently, Chikungunya and Zika. Guillain-Barre syndrome (GBS), microcephaly and all the encephalitides, have been of concern to public health officials in Latin America since the arrival of emerging arboviruses. iDon't forget about dengue!

Between 2014 and 2015 we received two unexpected and uninvited viruses: Chikungunya and Zika. Chikungunya, an alphavirus, appeared abruptly in developing countries of the Americas, revealing that we were not prepared to face it. While we were still recovering from Chikungunya, Zika virus arrived, only compounding the insult. One cannot imagine the potential impact of the introduction of a hemorrhagic virus of the likes of Marburg or Ebola in Latin America. This scenario would be catastrophic.

The mosquito vectors in Latin America are already in place to disseminate emergent arboviruses like Chikungunya, Zika, Mayaro, and Oropouche. The arrival of the mosquitoes preceded the viruses by 3.5 billion years and they are standing by to transport the viruses across the continent. Besides Aedes aegypti, the vector of Dengue, Chikungunya, and Zika viruses, mosquitoes of the genus Culex are common in Latin America and ready to participate in the dissemination of new and old arboviruses in urban, rural and peridomestic areas.

Health authorities in Europe, the USA, and Canada are concerned about Zika virus infection and the return of their citizens and athletes following the 2016 Olympic
En las zonas tropicales de América Latina, hemos sido testigos de la aparición de varios arbovirus patógenos en la última década. Estos incluyen los virus de la fiebre amarilla, Nilo Occidental, encefalitis de San Luis, encefalitis equina venezolana, Mayaro, Oropouche, Ilheus y más recientemente, Chikungunya y Zika. El síndrome de Guillain-Barré (GBS), microcefalia y todas las encefalitis, han sido motivo de preocupación para las autoridades de salud pública en América Latina desde la llegada de los arbovirus emergentes. iPero no olvidemos el dengue!

Entre 2014 y 2015 recibimos dos virus inesperados e indeseados: Chikungunya y Zika. Chikungunya, un alfavirus, que apareció bruscamente en los países en desarrollo de las Américas y reveló que no estábamos preparados para hacerles frente. Si bien todavía nos estábamos recuperando del Chikungunya, llegó el virus Zika, sólo para agravar la situación. Uno no puede imaginar el impacto potencial que tendría la introducción de un virus hemorrágico de la talla de Marburgo o Ébola en América Latina. Ese escenario sería catastrófico.

Los mosquitos vectores en América Latina ya están listos para difundir arbovirus emergentes como Chikungunya, Zika, Mayaro y Oropouche. La llegada de los mosquitos precedió a la de los virus por 3.5 billones de años y están en espera para transportar a los virus en todo el continente. Además de Aedes aegypti, vector del Dengue, Chikungunya, y los virus Zika, los mosquitos del género Culex son comunes en América Latina y están listos para participar en la difusión de nuevos y viejos arbovirus en zonas urbanas, rurales y peri-domésticas.

Las autoridades sanitarias de Europa, EE.UU. y Canadá están preocupadas por la infección del virus Zika y el regreso de sus ciudadanos y de los atletas después de los Juegos Olímpicos de 2016. Sin embargo, parecen estar olvidando los 
Games. Yet they seem to be forgetting about Dengue, Chikungunya, Mayaro, and Oropouche viruses. Dengue is still the most common vector-borne disease in Latin American. The incidences of common arbovirus infections in Latin America are very high: approximately 173 cases/100000 inhabitants for dengue, 8 cases/100000 inhabitants for chikungunya, and 45 cases/100000 inhabitants for Zika. These epidemiologic data demonstrate very clearly that dengue should be considered a much greater concern than Zika and chikungunya (1).

The immunologic systems of Europeans and North Americans have no antibodies to tropical arboviruses, leaving them virtually defenseless against them. Most athletes and spectators will leave the competition and return home rapidly; thus, the spread of potentially viremic individuals could be wide and rapid. Humans infected with chikungunya virus appear to experience longer viremia than with Zika, dengue, and Mayaro viruses; thus, the greatest risk of disease spread may be from returning travelers infected with chikungunya virus. Furthermore, visitors will return to their countries in summer when high temperatures could facilitate the dissemination of the virus into autochthonous mosquito populations.

Female tourists and athletes in the beginning of pregnancy when they reach Brazil may be at risk of congenital disorders of their fetus if they are infected with Zika virus. However, many questions remain: Why is there still no animal model? Is it only a monoinfection or are other microorganisms involved in the infection? Are immune complexes involved in the pathogenesis?

The task for Brazilian authorities is to decrease the number of mosquito bites. This can be approached by using biological control (e.g., Wolbachia and Toxorhynchites) and by educating the community to remove containers with water where the mosquitoes breed. Use of repellents and oral complex vitamin B can also be useful in reducing bites. However, as was Ebola in the recent past, emerging viruses will always be of great concern. We are living in a period of biological transition brought on by many factors including modern transportation, worldwide trade, and climate change. We must adapt to this new world where infections are inevitable. Research on the eco-epidemiology of vectors leading to a greater understanding of the dynamics of tropical infectious diseases will be an important part of that adaptation process. virus como el Dengue, Chikungunya, Mayaro y Oropouche. El Dengue sigue siendo la enfermedad más común transmitida por vectores en América Latina. La incidencia de las infecciones por arbovirus comunes en América Latina son muy altas: aproximadamente 173 casos/100000 habitantes para Dengue, 8 casos/100000 habitantes de Chikungunya y 45 casos/100000 habitantes para Zika. Estos datos epidemiológicos demuestran muy claramente que el Dengue debe ser considerado como una preocupación mucho mayor que el Zika y Chikungunya (1).

Los sistemas inmunológicos de los europeos y norteamericanos no tienen anticuerpos contra esos arbovirus tropicales, dejándolos prácticamente sin defensa contra ellos. La mayoría de los atletas y espectadores saldrán de la competencia y regresarán rápidamente a casa, por lo tanto, la propagación de individuos potencialmente virémicos podría ser amplia y rápida. Los seres humanos infectados con el virus de Chikungunya parecen experimentar una viremia de mayor tiempo que con los virus Zika, Dengue y Mayaro; por lo tanto, el mayor riesgo de propagación de la enfermedad puede ser al regresar viajeros infectados con el virus de Chikungunya. Además, los visitantes regresarán a sus países en verano, cuando las altas temperaturas podrían facilitar la difusión del virus en las poblaciones de mosquitos autóctonos.

Turistas y atletas femeninas que estén comenzando su embarazo cuando lleguen a Brasil, pueden estar en riesgo que sus fetos padezcan trastornos congénitos si ellas son infectadas con el virus Zika. Sin embargo, la relación entre Zika y trastornos congénitos necesita más estudio. Quedan muchas preguntas: ¿Por qué todavía no hay ningún modelo animal? ¿Es sólo una monoinfeccción o están otros microorganismos implicados en la infección? ¿Están los complejos inmunes implicados en la patogénesis?

La tarea de las autoridades brasileñas es disminuir el número de picaduras de mosquitos. Esto puede ser abordado mediante el uso de control biológico (por ejemplo, Wolbachia and Toxorhynchites) y educando a la comunidad de eliminar los recipientes con agua, donde los mosquitos se reproducen. El uso de repelentes y la administración oral de vitaminas del complejo B también pueden ser útiles en la reducción de las picaduras. Sin embargo, como fue Ébola en el pasado reciente, los virus emergentes siempre serán de gran preocupación. Estamos viviendo un período de transición biológica causado por muchos factores, incluyendo el transporte moderno, el comercio en todo el mundo y el cambio climático. Tenemos que adaptarnos a este nuevo mundo donde las infecciones son inevitables. La 
Why have we forgotten dengue? The annual economic impact of dengue in the Americas was estimated at US $\$ 2.6$ billion in 2010 . Ninetynine percent of these costs are derived from the cases of Latin America and the Caribbean. The average cost per case in North America is yet $10 x$ higher, estimated in 2010 at US\$ 382. There is no doubt that associated costs in the current arbovirus emergence scenario (Dengue+Chikungunya+Zika) in Latin America, will further impoverish and collapse public health systems in developing countries (3).
Salim Mattar V. Ph.D. investigación relacionada con eco-epidemiología de vectores que conduce a una mayor comprensión de la dinámica de las enfermedades infecciosas tropicales será una parte importante de ese proceso de adaptación.

¿Por qué hemos olvidado el Dengue? Se estimó que el impacto económico anual del Dengue en las Américas fue de 2,6 billones de dólares americanos en 2010. El noventa y nueve por ciento de estos costos se derivaron de los casos de América Latina y el Caribe. El promedio del costo por caso en América del Norte es hasta 10 veces más alto. No hay duda que los costos asociados en el escenario actual de infección por arbovirus (Dengue+Chikungunya+Zika) en América Latina, terminará empobreciendo y colapsando aún más los sistemas de salud pública de los países en vía de desarrollo (3).

\section{REFERENCES}

1. OPS/OMS. Number of Reported Cases of Dengue and Severe Dengue (SD) in the Americas, by Country: Figures for 2016 (to week noted by each country). Epidemiological Week / EW 16 (Updated April 29 2016). [En linea]. URL Available in: http://www.paho.org/hq/index. php?option $=$ com_docman\&task $=$ doc_dow nload\&Itemid $=\&$ gid $=34349$ \&lang $=e s$
2. Mattar S. Guillain-Barre syndrome, microcephaly and encephalitis, Is the recent incidence really due to Zika virus infection? Revista Laboratorio Actual 2016; 47:48-50

3. Shepard DS, Coudeville L, Halasa YA, Zambrano B, Dayan GH. Economic impact of dengue illness in the Americas. The American journal of tropical medicine and hygiene. $2011 ; 84(2): 200-7$. 